\title{
Disability adjusted life years lost due to acute, chronic disability and premature death in arterial hypertension
}

\author{
Vida saludable perdida por discapacidad aguda, crónica y muerte prematura en \\ hipertensión arterial
}

\author{
Enrique Villarreal-Ríos ${ }^{1 *}$, Griselda Montoya-Cruz ${ }^{1,2}$, Emma R. Vargas-Daza1, Liliana Galicia-Rodríguez, \\ Verónica Escorcia-Reyes ${ }^{3}$, and Laura A. Cu-Flores ${ }^{4}$ \\ ${ }^{1}$ Unidad de Investigación Epidemiológica y en Servicios de Salud Querétaro; ${ }^{2}$ Department of Family Medicine, Family Medicine Unit No 9; ${ }^{3}$ Family \\ Medicine Unit No 6, San Juan del Río; ${ }^{4}$ Family Medicine Unit No 16. Instituto Mexicano del Seguro Social (IMSS), Querétaro, Mexico
}

\begin{abstract}
Objective: To determine the disability adjusted life years in arterial hypertension without diabetes mellitus. Method: Disability adjusted life years was determined from chronic disability (chronic kidney disease, heart disease and cerebral vascular event), acute disability (hypertensive crisis and hypertensive emergency) and premature death. Age of diagnosis, age of the complication, prevalence of the complication, duration of the acute event, number of acute events, time lived with hypertension, age of death and life expectancy were identified. In all cases a $3 \%$ discount rate was applied, the estimate was made per 100,000. Results: When the total of women was used as a reference, the disability adjusted life years in women is 198,498.28. In men, using the total number of men as a reference, the value is $204,232.13$. If the referent is the total population, in women the disability adjusted life years is 102,028.11 and in men 99,256.98. Conclusions: The disability adjusted life years in arterial hypertension without diabetes is different for men and women; the topic has many edges that must be studied.
\end{abstract}

Key words: Disability adjusted life. Disability. Life expectancy. Arterial hypertension. Mortality.

\section{Resumen}

Objetivo: Determinar la vida saludable perdida por hipertensión arterial sin diabetes mellitus. Método: La vida saludable perdida se determinó a partir de la discapacidad crónica (enfermedad renal crónica, cardiopatía y evento vascular cerebral), la discapacidad aguda (crisis hipertensiva y emergencia hipertensiva) y la muerte prematura. Se identificaron la edad del diagnóstico, la edad de la complicación, la prevalencia de la complicación, la duración del evento agudo, el número de eventos agudos, el tiempo vivido con hipertensión, la edad de la muerte y la esperanza de vida. En todos los casos se aplicó una tasa de descuento del 3\%. La estimación se realizó por 100,000. Resultados: Cuando se utilizó como referencia el total de mujeres, la vida saludable perdida en ellas es de 198,498.28. Empleando como referencia el total de hombres, el valor para ellos es de 204,232.13. Si el referente es el total de la población, para las mujeres la vida saludable perdida es de 102,028.11 y para los hombres es de 99,256.98. Conclusiones: La vida sWaludable perdida por hipertensión arterial sin diabetes es diferente en hombres y mujeres; no obstante, tiene muchas aristas que deben abordarse.

Palabras clave: Años de vida saludables perdidos. Discapacidad. Esperanza de vida. Hipertensión arterial. Mortalidad.

Correspondencia:

*Enrique Villarreal-Ríos

E-mail: enriquevillarrealrios@gmail.com
Available online: 19-07-2021

2604-7063 / @ 2020 Instituto Nacional de Cardiología Ignacio Chávez. Published by Permanyer. This is an open access article under the CC BY-NC-ND license (http://creativecommons.org/licenses/by-nc-nd/4.0/).

Date of reception: 08-04-2020

Date of acceptance: 10-07-2020

DOI: 10.24875/ACME.M21000197
Arch Cardiol Mex (Eng). 2021;91(2):171-176
www.archivoscardiologia.com

Arch Cardiol Mex (Eng). 2021;91(2):171-176
www.archivoscardiologia.com 


\section{Introduction}

Currently, chronic diseases such as arterial hypertension constitute one of the biggest challenges faced by health systems worldwide ${ }^{1,2}$. In arterial hypertension, prevalence, acute complications and chronic complications are involved, manifested as hypertensive crisis, hypertensive emergency, heart failure, ischemic heart disease, cerebral vascular event, chronic kidney disease and hypertensive retinopathy, which translate into disability-adjusted life years ${ }^{3-6}$. In addition to complications, early age at hypertension onset increases the likelihood of premature death, which has an impact on disability-adjusted life years ${ }^{7-9}$. Complications and premature death translate into disability-adjusted life years; estimation of this indicator contemplates the sum of years of life lost due to premature death and years of life lost adjusted for acute or chronic disability ${ }^{10,11}$.

The original approach to disability-adjusted life years estimation was proposed for three large groups: communicable diseases, non-communicable diseases, and accidents and injuries. Hypertension was placed in the group of non-communicable diseases, in the subgroup of cardiovascular diseases. This proposal opens up the possibility for disability-adjusted life years in arterial hypertension to be identified ${ }^{12-14}$.

Regarding arterial hypertension, its high incidence in populations aged 20 years and older (31.1\%) should be recognized $^{6}$, in addition to the modification of its evolution when it coexists with other pathologies ${ }^{15}$.

In this context, the purpose of this article is to determine the disability-adjusted life years in arterial hypertension without diabetes mellitus.

\section{Method}

Descriptive, cross-sectional-design study in patients with arterial hypertension without diabetes mellitus. The information collection period took place from May to June 2019, at medical units of a social security system in Querétaro, Mexico. Patients with essential hypertension diagnosed by the family doctor and controlled in the primary care setting were included.

Disability-adjusted life years calculation was carried out for acute disability, chronic disability and premature death.

For acute and chronic disability estimation, the medical records of 270 patients with arterial hypertension without diabetes were analyzed. The sample size was calculated using the finite population means formula, with a $95 \%$ confidence level $(Z \alpha=1.64)$ for a null hypothesis rejection zone, assuming as hypothesis that the mean number of disability-adjusted life years per individual was greater than 11 , with a standard deviation of $1.41(s=1.41)$, margin of error of $0.14(d=0.14)$ and total population of $26,000(\mathrm{~N}=26,000)$. The sampling technique was by consecutive cases, using as a framework the list of hypertensive patients assigned to the medical unit.

The information generated from the medical record included patient current age, gender, prevalence of obesity and patient age at arterial hypertension diagnosis.

Hypertensive crisis and hypertensive emergency were included as part of acute disability; chronic kidney disease, heart disease and cerebrovascular event were considered for chronic disability.

With the information registered on the medical record, patient age at the time the complication was diagnosed, prevalence of the complication, duration of the acute event in days and number of acute events per year were identified.

The time lived (in years) with the complication was estimated based on the age at its onset and age at death.

To estimate the age of death occurrence in the population with arterial hypertension, life expectancy for this population was assumed to be 10 years less than in the general population, adopting as life expectancy for the Mexican population 77.8 years for women and 72.6 years for men ${ }^{16}$.

The number of years lived with hypertension were obtained by subtracting the age at hypertension diagnosis from the age at death. Life expectancy of the Japanese population was assumed: 82.5 years for women and 80.0 years for men ${ }^{17}$.

To identify acute and chronic disability-adjusted life years, a panel of five experts specialized in family medicine with more than 10 years of experience in clinical practice (responsible for monthly control of the patient with hypertension) identified the percentage of disability-adjusted life years by type of acute and chronic disability, weighted by the prevalence of the stage of each complication. The acute or chronic disability-adjusted life years estimation was applied a $3 \%$ discount rate.

For the estimation of disability-adjusted life years attributable to premature death, life expectancy at birth for the population of Japan was adopted (82.5 years for women and 80.0 years for men) $)^{17}$. Age of death occurrence in the population (already described) was identified 
and the years lost due to premature death were determined. The 3\% discount rate was applied.

Scenarios were projected using Mexico's population, $119,530,733$ inhabitants (INEGI), $51.4 \%$ of females $(61,474,620)$ and $48.6 \%$ of males $(58,056,133)$, the percentage of women aged 20 years or older, 33.5\% $(40,042,802)$, and the percentage of men aged 20 years or older, $29.9 \%(35,739,695)^{13}$. The prevalence of arterial hypertension in the population aged 20 years or older $(31.5 \%)$ was also adopted ${ }^{6}$.

The sources of information were patients, institutional records and experts. In all cases, informed consent of the interviewees was obtained.

The project was registered with the Institutional Research Committee and was carried out with the institution's own resources.

\section{Results}

Average age of the surveyed population was 45.77 years (95\% confidence interval [IC]: 42.86-48.68) in men and 50.64 years (95\% Cl: 48.34-52.92) in women. Prevalence of the female gender was $54.8 \%(95 \%$ $\mathrm{Cl}: 48.8-60.7)$, and of the male gender was $45.2 \%$ (95\% Cl: 39.3-51.2). Prevalence of overweight and obesity in men was $84.43 \%$ (95\% Cl: $77.9-90.9)$, and in women it was $89.1 \%$ (95\% Cl: 84.0-94.2).

Mean age at hypertension diagnosis was 43.61 years in women and 40.12 years in men. Table 1 shows the age at death and the time lived with hypertension, by gender.

Age at heart disease diagnosis was 46.50 years in women and 53.67 years in men. The prevalence of heart disease was $6.08 \%$ in women and $7.38 \%$ in men. The time lived with heart disease in women was 14.13 years, and in men it was 8.93 years. Table 2 provides this information for chronic kidney disease and cerebral vascular event.

Age at presentation of the first hypertensive crisis was 46.75 years in women and 41.87 years in men. Table 2 describes the remaining characteristics of acute disability.

The evaluation provided by the experts regarding chronic and acute disability-adjusted life years varied: $90.0 \%$ for hypertensive crisis and $1.97 \%$ for chronic kidney disease. Table 2 presents this information for the rest of complications.

Years lost due to premature death applying the 3\% discount rate are 9.52 in women and 10.40 in men. Table 3 presents the assumptions adopted to estimate
Table 1. Age at diagnosis, age at death and years lived with hypertension by gender

\begin{tabular}{|l|c|c|}
\hline Indicator & Women & Men \\
\hline Age at diagnosis (years) & 43.61 & 40.12 \\
\hline Age at death (years) & 67.80 & 62.60 \\
\hline Years lived with hypertension* & 24.19 & 22.48 \\
\hline
\end{tabular}

Assumption: the population with hypertension was assumed to live 10 years less than the general population. Life expectancy in the Mexican population: 77.8 years for women and 72.6 for men ${ }^{16}$.

${ }^{*}$ Age at death minus age at hypertension diagnosis.

disability-adjusted life years attributable to premature death.

Total number of years lost per 100,000 population is $102,028.11$ in women and 99,256.82 in men. Premature death is the dimension that contributes with more disability-adjusted life years: 100,453.60 in women and $97,985.83$ in men. Table 4 shows disability-adjusted life years by type of acute and chronic disability.

\section{Discussion}

Burden of disease has been widely studied ${ }^{18,19}$, but it is a reality that the presence of multiple pathologies is currently a common scenario; particularly, in hypertensive patients, there is a strong coexistence with diabetes, a distinction that in disability-adjusted life years analysis is rarely addressed. Hence the importance of the study herein presented, which shows disability-adjusted life years in hypertension without diabetes mellitus and, in particular, identifies the contribution of acute disability, chronic disability and premature death to disability-adjusted life years.

It should be noted that one of the strengths of this work is the estimation made by the experts to determine disability-adjusted life years, which included identification of the prevalence of chronic complications stages and the differentiated distribution of disability-adjusted life years by stage, which is an information that allows having a weighted value. It is true that there is The Global Burden of Disease and Injury study proposal for measuring disability, but the reality is that methods are extremely varied, although, in all of them, the principle is the same: to identify disability severity, a proposal that was adopted in this work ${ }^{20,21}$.

In patients with hypertension without diabetes mellitus, the dimension that most contributes to disability-adjusted life years is premature death, a trend that 
Table 2. Characteristics of chronic and acute disability by gender and according to the experts' evaluation of disability-adjusted life years

\begin{tabular}{|c|c|c|c|c|c|c|}
\hline \multirow[t]{3}{*}{ Characteristic } & \multicolumn{6}{|c|}{ Chronic disability } \\
\hline & Women & Men & Women & Men & Women & Men \\
\hline & \multicolumn{2}{|c|}{ Chronic kidney disease } & \multicolumn{2}{|c|}{ Heart disease } & \multicolumn{2}{|c|}{ Cerebral vascular event } \\
\hline Age at presentation (years) & 57.01 & 50.91 & 46.50 & 53.67 & 47.00 & 56.00 \\
\hline Years lived with the complication & 10.73 & 11.69 & 14.13 & 8.93 & 10.73 & 11.69 \\
\hline Prevalence of the complication (\%) & 10.14 & 18.85 & 6.08 & 7.38 & 2.70 & 1.64 \\
\hline Disability-adjusted life years (\%) & \multicolumn{2}{|c|}{1.97} & \multicolumn{2}{|c|}{10.80} & \multicolumn{2}{|c|}{25.60} \\
\hline \multirow[t]{3}{*}{ Characteristic } & \multicolumn{6}{|c|}{ Acute disability } \\
\hline & Women & Men & Women & \multicolumn{3}{|c|}{ Men } \\
\hline & \multicolumn{2}{|c|}{ Hypertensive crisis } & \multicolumn{4}{|c|}{ Hypertensive emergency } \\
\hline Age at first presentation (years) & 46.75 & 41.87 & 55.12 & & 52.00 & \\
\hline Years lived with the complication & 21.05 & 20.73 & 12.68 & & 10.60 & \\
\hline Prevalence of the complication (\%) & 3.38 & 6.56 & 1.35 & & 1.64 & \\
\hline Acute event duration (days) & 1.00 & 1.00 & 1.00 & & 1.00 & \\
\hline Number of events per year & 1.00 & 1.00 & 1.00 & & 1.00 & \\
\hline Disability-adjusted life years (\%) & 90.0 & & 90.0 & & & \\
\hline
\end{tabular}

Table 3. Assumptions adopted for estimating disabilityadjusted life years attributable to premature death

\begin{tabular}{|c|c|c|}
\hline Characteristic & Women & Men \\
\hline Life expectancy (years)* & 82.50 & 80.00 \\
\hline Age at death (years) & 67.80 & 62.60 \\
\hline Years lost due to premature death & 14.70 & 17.40 \\
\hline $\begin{array}{l}\text { Years lost due to premature death, } \\
\text { adjusted }^{\dagger}\end{array}$ & 9.52 & 10.40 \\
\hline
\end{tabular}

*Life expectancy of the population from Japan for women and men was adopted as reference ${ }^{17}$.

${ }^{\dagger} 3 \%$ discount rate.

is consistent with observations described in the literature $^{18}$. The difference in the contribution of acute disability and chronic disability is quite evident; however, it should be noted that experiencing premature death is a consequence of acute or chronic disability, and, therefore, the management of acute or chronic disability is an area of opportunity for health services to decrease the burden of disease in arterial hypertension.

Actually, disability-adjusted life years analysis in hypertension evaluates the population but, indirectly, it is a reflection of health services performance, since they are involved in the care of the population's health.

The estimation of disability-adjusted life years in hypertension without diabetes defines disability as those events regarded as acute or chronic complications of arterial hypertension, and these are the factors that contribute healthy life lost to the indicator. At this moment, the logical questioning is established around that which is measured; the complication is being measured or hypertension is being measured. Actually, any of the complications is an independent condition that could have another origin but, in the case of hypertension, they occur as an event that is secondary to the hypertensive process and, consequently, disability-adjusted life years should be attributed to it. The same occurs with premature mortality: death occurs as a consequence of chronic kidney disease or heart disease, but these conditions are secondary to arterial hypertension.

The reports on disability-adjusted life years in heart disease identify 841,187 disability-adjusted life years in men and 537,422 in women ${ }^{18}$. It will be necessary to determine whether disability-adjusted life years in arterial hypertension are part of that accounting, and the 
Table 4. Disability-adjusted life years attributable to chronic disability, acute disability, premature and total death in women and men on three scenarios

\begin{tabular}{|c|c|c|c|c|c|c|}
\hline \multirow[t]{3}{*}{ Indicator* } & \multicolumn{2}{|c|}{ Scenario 1} & \multicolumn{2}{|c|}{ Scenario 2} & \multirow{2}{*}{\multicolumn{2}{|c|}{$\begin{array}{c}\text { Scenario } 3 \\
\text { Total population }\end{array}$}} \\
\hline & Women aged 20 & Men aged 20 years & All women & All men & & \\
\hline & & & & & Women & Men \\
\hline $\begin{array}{l}\text { Chronic disability } \\
\text { Kidney disease } \\
\text { Heart disease } \\
\text { Cerebrovascular event sequel } \\
\text { Total }\end{array}$ & $\begin{array}{c}491.54 \\
2,347.80 \\
1,703.32 \\
4,542.66\end{array}$ & $\begin{array}{c}967.87 \\
1,721.68 \\
1,093.69 \\
3,783.24\end{array}$ & $\begin{array}{c}320.36 \\
1,530.18 \\
1,110.14 \\
2,960.68\end{array}$ & $\begin{array}{c}595.46 \\
1,059.22 \\
672.87 \\
2,327.55\end{array}$ & $\begin{array}{c}164.66 \\
786.51 \\
570.61 \\
1,521.79\end{array}$ & $\begin{array}{c}289.39 \\
514.78 \\
327.01 \\
1,131.19\end{array}$ \\
\hline $\begin{array}{l}\text { Acute disability } \\
\text { Hypertensive crisis } \\
\text { Hypertensive emergency } \\
\text { Total }\end{array}$ & $\begin{array}{c}148.24 \\
9.15 \\
157.39\end{array}$ & $\begin{array}{c}457.68 \\
9.87 \\
467.55\end{array}$ & $\begin{array}{c}96.62 \\
5.96 \\
102.58\end{array}$ & $\begin{array}{c}281.58 \\
6.07 \\
287.65\end{array}$ & $\begin{array}{c}49.66 \\
3.06 \\
52.73\end{array}$ & $\begin{array}{c}136.85 \\
2.95 \\
139.80\end{array}$ \\
\hline $\begin{array}{l}\text { Premature death } \\
\text { Total }\end{array}$ & $\begin{array}{l}299,861.48 \\
299,861.48\end{array}$ & $\begin{array}{l}327,711.81 \\
327,711.81\end{array}$ & $\begin{array}{l}195,435.01 \\
195,435.01\end{array}$ & $\begin{array}{l}201,616.94 \\
201,616.94\end{array}$ & $\begin{array}{l}100,453.60 \\
100,453.60\end{array}$ & $\begin{array}{l}97,985.83 \\
97,985.83\end{array}$ \\
\hline $\begin{array}{l}\text { Total } \\
\text { Total }\end{array}$ & $304,561.54$ & $331,962.60$ & $198,498.28$ & $204,232.13$ & $102,028.11$ & $99,256.82$ \\
\hline
\end{tabular}

*Per 100,000 .

same consideration applies to disability-adjusted life years in the setting of chronic kidney disease and cerebral vascular events, among others.

When disability-adjusted life years are compared between men and women, there is a heavier burden on men when the group of men or women is used as reference. This is consistent with literature reports ${ }^{18}$. However, when the entire population is used as reference, the trend is modified.

It is true that, in this work, the estimation of chronic disability-adjusted life years does not include myocardial ischemia or hypertensive retinopathy, but this does not disqualify the results, which will have to be complemented in other investigations.

Undoubtedly, disability-adjusted life years estimation will be modified according to the population taken as reference, an obvious scenario when the results are presented for the entire population, for women and men, and for people older than 20 years. It is true that the benchmark is already established for making comparisons with other populations, but an analysis of the different scenarios is mandatory as part of the study on the subject.

Finally, the essence of research is the generation of knowledge by knowledge, but at the end of the road, knowledge is used to the benefit of society and, in this sense, it must be clear in what or for what knowledge on disability-adjusted life years in hypertension without diabetes mellitus can be used and, moreover, who is the user of the knowledge: the clinician, the epidemiologist or the decision-making officer for establishing the rules in matters of public policies; the answer appears to go well beyond the purposes of this article.

\section{Conclusions}

Disability-adjusted life years in arterial hypertension without diabetes is different in men and women; however, the issue has many edges that need to be addressed.

\section{Funding}

This research has not received any specific grant from public, commercial or non-profit sector agencies.

\section{Conflicts of interest}

None.

\section{Ethical disclosures}

Protection of human and animal subjects. The authors declare that no experiments have been performed on humans or animals for this research. 
Confidentiality of data. The authors declare that they have followed the protocols of their work center on the publication of patient data.

Right to privacy and informed consent. The authors declare that no patient data appear in this article.

\section{References}

1. Instituto Mexicano del Seguro Social. Diagnóstico y tratamiento de la hipertensión arterial en el adulto mayor. Guía de evidencias y recomendaciones. Guía de práctica clínica. México: Instituto Mexicano del Seguro Social; 2017. Disponible en: http://www.imss.gob.mx/sites/all/statics/ guiasclinicas/238GER.pdf.

2. Secretaría de Integración y Desarrollo del Sector Salud. Informe sobre la salud de los mexicanos 2015. Diagnóstico general de la salud poblacional. México: Secretaría de Salud; 2015. Disponible en: https://www. gob.mx/cms/uploads/attachment/file/64176/INFORME_LA_SALUD_DE_ LOS MEXICANOS 2015 S.pdf.

3. Soto Estrada G, Moreno Altamirano L, Pahua Díaz D. Panorama epidemiológico de México, principales causas de morbilidad y mortalidad Revista de la Facultad de Medicina de la UNAM. 2016:59:8-22.

4. Secretaría de Salud, Instituto Nacional de Salud Pública. Encuesta Nacional de Salud y Nutrición de Medio Camino 2016. Informe final de resultados. México: Secretaría de Salud; 2016. Disponible en: https:// www.gob.mx/cms/uploads/attachment/file/209093/ENSANUT.pdf.

5. Rivero O, Martínez A. Hipertensión arterial. Prevalencia y factores de riesgo en la población de un consultorio de Morón. Convenio Internacional de Salud. Cuba; 2018. Disponible en: http://www.convencionsalud2018.sld.cu/index.php/connvencionsalud/2018/paper/view/364/430

6. Campos Nonato I, Hernández Barrera L, Pedroza Tobías A, Medina C Barquera S. Hipertensión arterial en adultos mexicanos: prevalencia diagnóstico y tipo de tratamiento. Ensanut MC 2016. Salud Pública de México. 2018;60:233-43.

7. Ramos MV. Hipertensión arterial: novedades de las guías 2018. Rev Urug Cardiol. 2019;34:53-60.

8. Santeiro Pérez L, Valdés Gómez M, Díaz Quiñones J, Díaz Marrero J Sarmiento Albelo $Y$. Años de vida potencialmente perdidos por primeras causas de muerte. Rev Finlay. 2018;8(3). Disponible en: http://revfinlay. sld.cu/index.php/finlay/article/view/602.
9. Pompa SG, Duany LF, Tamayo BDC, Álvarez A, Fonseca RL. Nefropatía hipertensiva: factores de riesgo en pacientes pertenecientes al policlínico Jimmy Hirzel. Revista 16 de Abril. 2018;57:80-8. Disponible en: https:// www.medigraphic.com/pdfs/abril/abr-2018/abr18268d.pdf.

10. Frenk J, Ruelas E, Bobadilla JL, Zurita B, Lozano R, González Block MG, et al. Economía y salud: propuestas para el avance del sistema de salud en México. Informe final. México D.F.: Fundación Mexicana para la Salud; 1994.

11. Lozano R, Franco Marina F, Solís P. El peso de la enfermedad crónica en México. Salud Publica de México. 2007;49:E283-7.

12. Serra Valdés M, Serra Ruiz M, Viera García M. Las enfermedades crónicas no transmisibles: magnitud actual y tendencias futuras. Rev Finlay. 2018;8(2). Disponible en: http://scielo.sld.cu/scielo.php?script=sci_arttext\&pid=S2221-24342018000200008\&lng=es.

13. Instituto Nacional de Estadística y Geografía. Mujeres y hombres en México 2018. México: Instituto Nacional de Estadística y Geografía 2018. Disponible en: http://cedoc.inmujeres.gob.mx/documentos_download/MHM_2018.pdf.

14. Ríos Blancas MJ, Cahuana Hurtado L, Lamadrid Figueroa H, Lozano R. Cobertura efectiva del tratamiento de la hipertensión arterial en adultos en México por Entidad Federativa. Salud Pública de México. 2017;59: 154-64.

15. Araya-Orozco M. Hipertensión arterial y diabetes mellitus. Rev Costarric Cienc Med. 2004;25:65-71.

16. Instituto Nacional de Geografía y Estadística. Esperanza de vida. México. Disponible en: http://cuentame.inegi.org.mx/poblacion/esperanza.aspx?tema=P.

17. Murruy C. Cuantificación de la carga de enfermedad: la base ética del cálculo de los años de vida ajustados en función de la discapacidad. Bol Oficina Sanit Panam. 1995;118:221-43.

18. Lozano R, Gómez Dantés $H$, Garrido Latorre F, Jiménez Corona A, Campuzano Rincón JC, Franco Marina F, et al. La carga de enfermedad, lesiones, factores de riesgo y desafíos para el sistema de salud en México. Salud Pública de México. 2013;55:580-94.

19. Murray C, López A. Quantifying disability: data, methods and results. WHO Bulletin OMS. 1994;72:481-94.

20. Organización Mundial de la Salud, Banco Mundial. Informe mundial sobre la discapacidad. Malta: Organización Mundial de la Salud; 2011. Disponible en: https://www1.paho.org/arg/images/Gallery/Informe_spa.pdf.

21. Murray $\mathrm{C}$, López $\mathrm{A}$. The global burden of disease and injury series. Cambridge: World Health Organization; 1996. Disponible en: https://apps. who.int/iris/bitstream/handle/10665/41864/0965546608_eng.pdf?sequence $=1$ \&isAllowed $=y$. 